\title{
Congenital syphilis in Brazil: distribution of cases notified from 2009 to 2016
}

\author{
Adriana Sousa Rêgo ${ }^{[1],}$ Luciana Cavalcante Costa ${ }^{[2]}$, Liliane dos Santos Rodrigues ${ }^{[3]}$, \\ Ricardo Amorim de Sousa Garcia ${ }^{[1]}$, Flor de Maria Araújo Mendonça Silva ${ }^{[1]}$, \\ Aurean D'eça Junior ${ }^{[4]}$ and Livia dos Santos Rodrigues ${ }^{[5]}$
}

[1]. Centro Universitário do Maranhão, Programa de Pós-Graduação em Gestão de Programas e Serviços de Saúde, São Luís, MA, Brasil.

[2]. Universidade Federal do Maranhão, Centro de Pesquisas, Departamento de Saúde Pública, São Luís, MA, Brasil.

[3]. Universidade Federal do Maranhão, Departamento de Biologia, São Luís, MA, Brasil.

[4]. Universidade Federal do Maranhão, Departamento de Enfermagem, São Luís, MA, Brasil.

[5]. Universidade de São Paulo, Faculdade de Medicina de Ribeirão Preto, Departamento de Puericultura e Pediatria, Ribeirão Preto, SP, Brasil.

\begin{abstract}
Introduction: Congenital syphilis is considered a severe public health problem because it accounts for approximately $40 \%$ of the perinatal mortality rates, $25 \%$ of stillbirths, and $14 \%$ of neonatal deaths, in addition to causing severe consequences for the fetus. This study aimed to describe the rates of congenital syphilis in children under one year of age in Brazilian capitals from 2009 to 2016. Methods: Ecological time series study, using rates of congenital syphilis in children under one year of age and living in Brazilian capitals. The Prais-Winsten regression model was used to assess the trend. Results: A total of 44,056 cases of congenital syphilis in children under one year of age were reported in Brazilian capitals between 2009 and 2016. The highest rate of congenital syphilis in children under one year of age occurred in 2016 in Porto Alegre (31.07/1,000 live births). The Northeastern capitals showed high rates, particularly the capital Recife (23.67/1,000 live births). Conclusions: Congenital syphilis represents a major challenge for public policies. The need for improvements in the quality of prenatal care is highlighted, as it is essential to reduce the alarming rates.
\end{abstract}

Keywords: Congenital Syphilis. Time Series Studies. Public Health.

\section{INTRODUCTION}

Syphilis, which is caused by the Treponema pallidum bacterium, is an infectious disease that can be transmitted through intimate contact, sexual intercourse, or during the gestational period (transmission from mother to child). This latter type of infection is referred to as congenital syphilis ${ }^{1,2}$, and may occur transplacentally or during delivery ${ }^{3}$.

Syphilis treatment is easy to access and simple to perform and therefore, it management during pregnancy should be straightforward. The diagnosis and treatment should be performed in a timely manner in the early period of pregnancy. However,

\footnotetext{
Corresponding author: Adriana Sousa Rêgo

e-mail: adricefs@yahoo.com.br

(i) https://orcid.org/0000-0002-2494-030X

Received 28 July 2020

Accepted 25 August 2020
}

being a sexually transmitted infection (STI) makes it a difficultto-approach situation, especially when experienced in a sensitive moment (pregnancy).

This implies that the quality of prenatal care is a key aspect for the diagnosis and a consequent improvement in syphilis control. This can be done with improvement in access, coverage, and quality of care at the primary level, and promotion of the right to the Venereal Disease Research Laboratory (VDRL) test in the first prenatal care consultation, in the third trimester of pregnancy, and at the time of hospitalization for childbirth. Another important point for reducing syphilis is the treatment of the partners, a procedure that prevents reinfection ${ }^{4}$.

The severity of the congenital syphilis situation can be seen in the high number of reported cases. As shown in the Syphilis Epidemiological Bulletin (2019) $)^{5}$, between the years 2008 and 2018 there were 26,219 cases of congenital syphilis reported in Brazil; however, there was an increase of $5.2 \%$ in the number of 
cases observed from 2017 to 2018, with cases in the Northeast and Southeast regions being the most frequent. This increasing trend in the data was already present in the 2019 bulletin $^{5}$.

A national study, with 23,894 mothers, carried out in 2011-2012 through hospital interviews, data from medical records, and prenatal cards, estimated an incidence of congenital syphilis of 3.51 per thousand live births (95\% CI: 2.29-5.37) and a vertical transmission rate of $34.3 \%$ (95\% CI: 24.7-45.4) , varying from 1.35 per thousand in the Midwest Region to 4.03 per thousand in the Northeast Region?

The incidence rates of congenital syphilis in the state of Santa Catarina increased significantly $(+1,190 \%)$. The same was seen in all the macro-regions in the studied period from 2007 to 2016, with predominance in children of Caucasian women with low schooling and under 20 years of age ${ }^{8}$.

In the time trend and the spatial distribution of congenital syphilis in the state of Rio Grande do Sul (RS), of the 1,718,651 children born in the state between the years 2001 and 2012, 3,613 were notified and confirmed cases of CS9.

According to Furtado et al. ${ }^{10}$, the absence of treatment against congenital syphilis can have severe consequences for the baby, such as prematurity, abortion, and several types of sequelae. These sequelae vary according to the type of congenital syphilis.

Congenital syphilis is subdivided into two types. The first, referred to as precocious, occurs when the clinical manifestations of the disease occur between 0 and 2 years of age, with the following as its main examples: low birth weight, skin lesions, respiratory distress, anemia, jaundice, and pseudoparalysis of the limbs. In the second type, referred to as late, the child over 2 years of age may have an elevated palatal arch, neurological deafness, Clutton joints, and learning difficulties, among other health problems ${ }^{11}$.

Given the above, this study aimed to describe the rates of congenital syphilis in children under one year of age living in Brazilian capitals from 2009 to 2016.

\section{METHODS}

This is a time series ecological study in which the rates of congenital syphilis were analyzed in children under one year of age residing in Brazilian capitals (Porto Velho, Rio Branco, Manaus, Boa Vista, Belém, Macapá, Palmas, São Luís, Teresina, Fortaleza, Natal, João Pessoa, Recife, Maceió, Aracaju, Salvador, Belo Horizonte, Vitória, Rio de Janeiro, São Paulo, Curitiba, Florianópolis, Porto Alegre, Campo Grande, Cuiabá, Goiânia, and Brasília).

The descriptive analysis of the confirmed cases recorded the following parameters: prenatal care (yes or no), maternal syphilis (during prenatal care, at the time of delivery, after delivery, or not performed), treatment of the partner (yes or no), and evolution (alive, death due to the notified illness, or death due to another cause) from 2009 to 2016.

Data collection was carried out through the information systems of the Informatics Department of the Unified Health System (DATASUS). To calculate the rate of congenital syphilis in children under one year of age, the number of confirmed cases by capital of residence in the period from 2009 to 2016 provided by the Notification Diseases Information System (Sistema de Informação de Agravos de Notificação, SINAN) was used as numerator and, as denominator, the number of live births to mothers living in the same place and period obtained from the Live Birth Information System (Sistema de Informações sobre Nascidos Vivos, SINASC), multiplied by one thousand.

The analyses were performed using Stata 14.0 statistical software (StataCorp, Texas, USA), and the results were displayed through graphs and tables with relative and absolute frequencies.

Since it used data in the public domain and in accordance with Resolution No. 466 of December $12^{\text {th }}, 2012$ of the National Health Council (Conselho Nacional de Saúde, CNS), this study was exempted from consideration by the Research Ethics Committee.

\section{RESULTS}

A total of 44,056 congenital syphilis cases were reported in children under one year of age in Brazilian capitals from 2009 to 2016. In all the capitals, the majority of mothers attended prenatal care visits, especially in Boa Vista, with a percentage reaching $90.2 \%$. In the Northeastern capitals, with the exception of Teresina, Rio Branco, Manaus, and Belém, the diagnosis of maternal syphilis occurred only at the time of delivery. Macapá was the only capital where the highest percentage of maternal syphilis diagnoses had occurred after delivery (37.2\%). In the rest of the capitals (Porto Velho, Boa Vista, Palmas, and all those in the South and Southeast regions), the diagnosis of maternal syphilis occurred during prenatal care, with Curitiba standing out with the highest percentage (72.0\%). In all the capital cities, in most cases, the treatment of the partner was not addressed, especially in Aracaju (94.4\%) (Table 1).

The biggest oscillations, by region, were observed in the following capitals: Manaus (North), from 3.10/1000 live births in 2009 to 10.83/1000 live births 2016 (Table 2 and Figure 1); Teresina (Northeast), from 0.22/1000 live births in 2009 to 6.31/1000 live births in 2015 (it is important to highlight that the Northeastern capitals presented high rates, especially Recife, with 23.67/1000 live births) (Table 2 and Figure 1); Rio de Janeiro (Southeast), from 2.29/1000 live births in 2009, reaching 19.14/1000 live births in 2012 and 16.07/1000 live births in 2015 (Table 2 and Figure 2); Porto Alegre (South), from 9.48/1000 live births in 2009 to $31.07 / 1000$ live births in 2016 , the highest rate of congenital syphilis in the studied historical series (Table 2 and Figure 2); and Campo Grande (Midwest), from 2.34/1000 live births in 2009 to 10.05/1000 live births in 2016 (Table 2 and Figure 3).

\section{DISCUSSION}

This study highlights the performance of prenatal care with satisfactory percentages in all Brazilian capitals, especially when it comes to the diagnosis of maternal syphilis. However, the quality of prenatal care can still be improved in a minority of capitals where the diagnosis of maternal syphilis was made only at the time of delivery or postpartum. It is also important to emphasize that not treating the partner of the woman identified as having syphilis persists as a public health problem. 
TABLE 1: Characteristics of the notified cases of congenital syphilis in children under one year of age according to prenatal care, maternal syphilis, and treatment of the partner in Brazilian capitals from 2009 to 2016.

\begin{tabular}{|c|c|c|c|c|c|c|c|c|c|c|c|c|c|c|c|c|}
\hline \multirow{3}{*}{$\begin{array}{l}\text { Capital of } \\
\text { residence }\end{array}$} & \multicolumn{4}{|c|}{ Prenatal care } & \multicolumn{8}{|c|}{ Maternal syphilis } & \multicolumn{4}{|c|}{ Treatment of the partner } \\
\hline & \multicolumn{2}{|c|}{ Yes } & \multicolumn{2}{|c|}{ No } & \multicolumn{2}{|c|}{$\begin{array}{l}\text { During prenatal } \\
\text { care }\end{array}$} & \multicolumn{2}{|c|}{$\begin{array}{l}\text { At the time of } \\
\text { delivery }\end{array}$} & \multicolumn{2}{|c|}{ After delivery } & \multicolumn{2}{|c|}{$\begin{array}{c}\text { Not } \\
\text { performed }\end{array}$} & \multicolumn{2}{|c|}{ Yes } & \multicolumn{2}{|c|}{ No } \\
\hline & $\mathbf{N}$ & $\%$ & $\mathbf{N}$ & $\%$ & $\mathbf{N}$ & $\%$ & $\mathbf{N}$ & $\%$ & N & $\%$ & $\mathbf{N}$ & $\%$ & $\mathbf{N}$ & $\%$ & N & $\%$ \\
\hline Porto Velho & 222 & 80.7 & 53 & 19.3 & 141 & 50.0 & 100 & 35.5 & 39 & 13.8 & 2 & 0.7 & 33 & 13.8 & 207 & 86.3 \\
\hline Rio Branco & 167 & 76.6 & 51 & 23.4 & 72 & 33.8 & 115 & 54.0 & 24 & 11.3 & 2 & 0.9 & 24 & 11.3 & 189 & 88.7 \\
\hline Manaus & 1,006 & 69.9 & 434 & 30.1 & 562 & 39.3 & 758 & 53.0 & 101 & 7.1 & 9 & 0.6 & 308 & 30.8 & 691 & 69.2 \\
\hline Boa Vista & 165 & 90.2 & 18 & 9.8 & 84 & 45.2 & 83 & 44.6 & 17 & 9.1 & 2 & 1.1 & 35 & 20.2 & 138 & 79.8 \\
\hline Belém & 385 & 69.9 & 166 & 30.1 & 168 & 30.7 & 273 & 49.9 & 105 & 19.2 & 1 & 0.2 & 76 & 17.9 & 349 & 82.1 \\
\hline Macapá & 363 & 77.1 & 108 & 22.9 & 163 & 33.3 & 138 & 28.2 & 182 & 37.2 & 6 & 1.2 & 80 & 21.9 & 286 & 78.1 \\
\hline Palmas & 208 & 85.2 & 36 & 14.8 & 129 & 52.4 & 107 & 43.5 & 8 & 3.3 & 2 & 0.8 & 29 & 13.2 & 190 & 86.8 \\
\hline São Luís & 516 & 76.3 & 160 & 23.7 & 198 & 33.7 & 338 & 57.5 & 46 & 7.8 & 6 & 1.0 & 80 & 15.6 & 433 & 84.4 \\
\hline Teresina & 554 & 80.1 & 138 & 19.9 & 336 & 48.6 & 277 & 40.1 & 72 & 10.4 & 6 & 0.9 & 175 & 26.6 & 484 & 73.4 \\
\hline Fortaleza & 3,387 & 74.0 & 1.191 & 26.0 & 2,123 & 46.6 & 2,143 & 47.0 & 266 & 5.8 & 28 & 0.6 & 626 & 15.3 & 3,459 & 84.7 \\
\hline Natal & 794 & 80.4 & 194 & 19.6 & 420 & 42.1 & 506 & 50.8 & 68 & 6.8 & 3 & 0.3 & 184 & 22.6 & 631 & 77.4 \\
\hline João Pessoa & 370 & 79.2 & 97 & 20.8 & 163 & 35.0 & 256 & 54.9 & 42 & 9.0 & 5 & 1.1 & 90 & 22.3 & 313 & 77.7 \\
\hline Recife & 1,991 & 78.8 & 535 & 21.2 & 983 & 36.2 & 1,548 & 57.0 & 168 & 6.2 & 15 & 0.6 & 279 & 14.7 & 1,621 & 85.3 \\
\hline Maceió & 945 & 78.7 & 256 & 21.3 & 360 & 26.8 & 773 & 57.5 & 210 & 15.6 & 2 & 0.1 & 107 & 9.5 & 1,023 & 90.5 \\
\hline Aracaju & 341 & 55.9 & 269 & 44.1 & 220 & 35.3 & 366 & 58.7 & 37 & 5.9 & 0 & 0.0 & 34 & 5.6 & 578 & 94.4 \\
\hline Salvador & 1,328 & 74.3 & 459 & 25.7 & 945 & 43.9 & 965 & 44.8 & 229 & 10.6 & 14 & 0.7 & 279 & 18.8 & 1,205 & 81.2 \\
\hline Belo Horizonte & 1,121 & 85.8 & 185 & 14.2 & 900 & 69.1 & 319 & 24.5 & 74 & 5.7 & 9 & 0.7 & 173 & 17.6 & 812 & 82.4 \\
\hline Vitória & 261 & 84.2 & 49 & 15.8 & 210 & 67.7 & 77 & 24.8 & 23 & 7.4 & 0 & 0.0 & 33 & 11.7 & 249 & 88.3 \\
\hline Rio de Janeiro & 7,650 & 82.4 & 1.635 & 17.6 & 4,753 & 50.3 & 4.146 & 43.9 & 500 & 5.3 & 53 & 0.6 & 1,298 & 18.0 & 5,912 & 82.0 \\
\hline São Paulo & 4,903 & 72.2 & 1.891 & 27.8 & 3,751 & 54.5 & 2,871 & 41.7 & 225 & 3.3 & 36 & 0.5 & 1,183 & 19.4 & 4,908 & 80.6 \\
\hline Curitiba & 686 & 84.7 & 124 & 15.3 & 584 & 72.0 & 182 & 22.4 & 42 & 5.2 & 3 & 0.4 & 96 & 12.8 & 656 & 87.2 \\
\hline Florianópolis & 202 & 86.3 & 32 & 13.7 & 156 & 62.2 & 76 & 30.3 & 18 & 7.2 & 1 & 0.4 & 54 & 24.5 & 166 & 75.5 \\
\hline Porto Alegre & 2,209 & 77.9 & 625 & 22.1 & 1,724 & 62.6 & 915 & 33.2 & 110 & 4.0 & 7 & 0.3 & 336 & 18.3 & 1,496 & 81.7 \\
\hline Campo Grande & 501 & 82.3 & 108 & 17.7 & 366 & 59.3 & 179 & 29.0 & 71 & 11.5 & 1 & 0.2 & 76 & 13.4 & 491 & 86.6 \\
\hline Cuiabá & 250 & 76.5 & 77 & 23.5 & 173 & 51.3 & 133 & 39.5 & 26 & 7.7 & 5 & 1.5 & 26 & 11.7 & 197 & 88.3 \\
\hline Goiânia & 198 & 65.8 & 103 & 34.2 & 173 & 55.1 & 94 & 29.9 & 43 & 13.7 & 4 & 1.3 & 62 & 23.3 & 204 & 76.7 \\
\hline Brasília & 983 & 84.3 & 183 & 15.7 & 699 & 60.9 & 329 & 28.7 & 110 & 9.6 & 10 & 0.9 & 247 & 23.9 & 786 & 76.1 \\
\hline
\end{tabular}


Rêgo AS et al. - Congenital syphilis in Brazil

TABLE 2: Congenital syphilis rates in children under one year of age in Brazilian capitals from 2009 to 2016.

\begin{tabular}{|c|c|c|c|c|c|c|c|c|}
\hline $\begin{array}{l}\text { Capital of } \\
\text { residence }\end{array}$ & 2009 & 2010 & 2011 & 2012 & 2013 & 2014 & 2015 & 2016 \\
\hline \multicolumn{9}{|l|}{ North } \\
\hline Porto Velho & 0.13 & 0.86 & 2.28 & 3.01 & 5.15 & 6.02 & 7.47 & 7.43 \\
\hline Rio Branco & 4.43 & 1.39 & 1.44 & 2.60 & 6.60 & 6.98 & 5.88 & 3.17 \\
\hline Manaus & 3.10 & 2.23 & 2.54 & 3.71 & 4.56 & 3.15 & 6.37 & 10.83 \\
\hline Boavista & 3.89 & 5.79 & 3.35 & 6.29 & 6.14 & 1.77 & 1.19 & 1.62 \\
\hline Belém & 2.06 & 1.49 & 1.50 & 2.33 & 1.46 & 3.57 & 6.87 & 8.93 \\
\hline Macapá & 8.81 & 7.20 & 6.38 & 10.56 & 10.06 & 2.85 & 3.26 & 6.22 \\
\hline Palmas & 3.91 & 2.91 & 4.92 & 6.80 & 7.45 & 8.13 & 10.19 & 6.17 \\
\hline \multicolumn{9}{|l|}{ Northeast } \\
\hline São Luís & 1.74 & 1.15 & 3.11 & 3.986 & 7.32 & 6.41 & 9.76 & 8.03 \\
\hline Teresina & 0.22 & 1.18 & 1.79 & 3.330 & 5.91 & 6.67 & 16.31 & 15.36 \\
\hline Fortaleza & 12.61 & 12.07 & 14.12 & 16.39 & 16.59 & 17.59 & 16.85 & 19.43 \\
\hline Natal & 8.83 & 7.62 & 8.93 & 11.21 & 9.03 & 10.11 & 16.83 & 15.28 \\
\hline Joao Pessoa & 2.27 & 2.26 & 3.86 & 6.81 & 5.71 & 8.82 & 10.73 & 0.93 \\
\hline Recife & 8.11 & 9.95 & 13.36 & 12.37 & 18.38 & 19.56 & 23.15 & 23.67 \\
\hline Maceió & 4.93 & 7.56 & 11.12 & 14.92 & 14.82 & 14.91 & 12.72 & 11.05 \\
\hline Aracaju & 4.29 & 5.12 & 6.36 & 12.69 & 10.45 & 10.84 & 7.34 & 9.02 \\
\hline Salvador & 1.02 & 2.58 & 5.08 & 7.61 & 11.21 & 11.26 & 13.07 & 16.76 \\
\hline \multicolumn{9}{|l|}{ Southeast } \\
\hline Belo Horizonte & 1.39 & 2.34 & 2.25 & 5.50 & 6.15 & 7.43 & 9.00 & 10.08 \\
\hline Vitoria & 2.47 & 4.37 & 6.75 & 7.77 & 13.09 & 9.57 & 12.16 & 14.87 \\
\hline Rio de Janeiro & 2.29 & 11.04 & 17.18 & 19.14 & 18.54 & 17.17 & 15.65 & 16.07 \\
\hline São Paulo & 2.42 & 3.13 & 3.84 & 5.69 & 7.07 & 5.61 & 5.79 & 6.68 \\
\hline \multicolumn{9}{|l|}{ South } \\
\hline Curitiba & 1.72 & 2.09 & 3.32 & 3.54 & 4.29 & 5.52 & 6.36 & 6.24 \\
\hline Florianópolis & 0.95 & 1.88 & 2.20 & 2.72 & 8.88 & 10.32 & 7.82 & 8.98 \\
\hline Porto Alegre & 9.48 & 11.62 & 14.69 & 16.33 & 18.49 & 21.73 & 29.65 & 31.07 \\
\hline \multicolumn{9}{|l|}{ Midwest } \\
\hline Campo Grande & 2.34 & 3.04 & 3.98 & 6.49 & 6.71 & 6.19 & 7.11 & 10.05 \\
\hline Cuiabá & 1.81 & 2.03 & 1.30 & 4.49 & 6.71 & 6.35 & 7.76 & 4.15 \\
\hline Goiânia & 0.20 & 0.19 & 0.82 & 0.84 & 1.63 & 3.00 & 3.62 & 4.49 \\
\hline Brasília & 1.88 & 2.10 & 2.76 & 3.33 & 3.97 & 3.91 & 4.37 & 5.02 \\
\hline
\end{tabular}

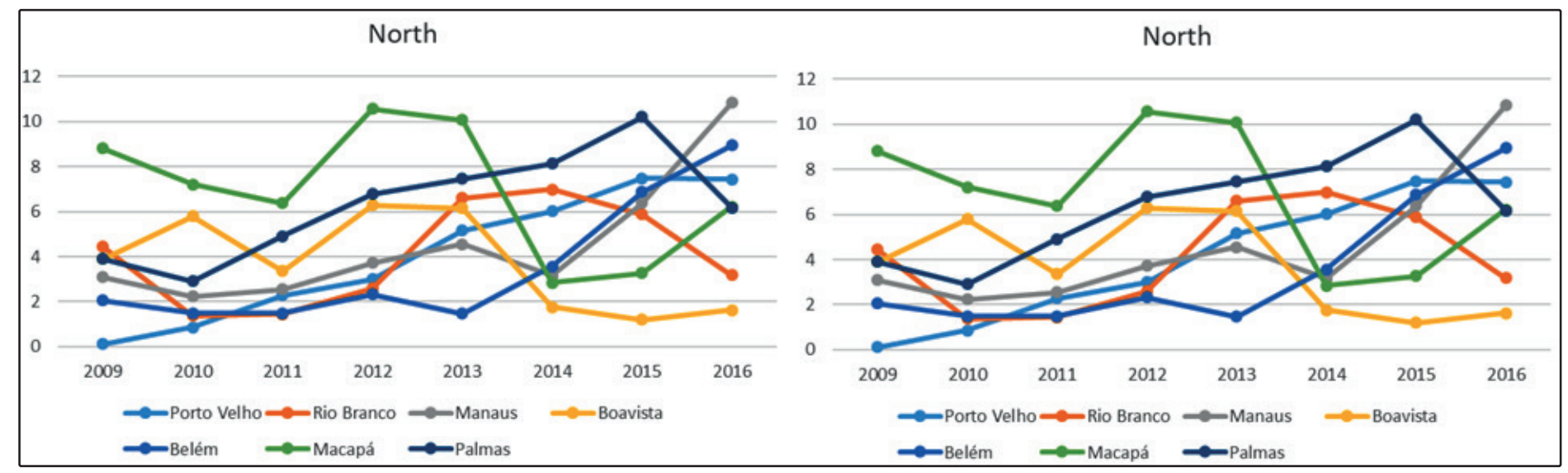

FIGURE 1: Distribution of congenital syphilis rates* in children under one year of age living in the capitals of the North and Northeast regions of Brazil from 2009 to 2016. *Per 1000 live births. 


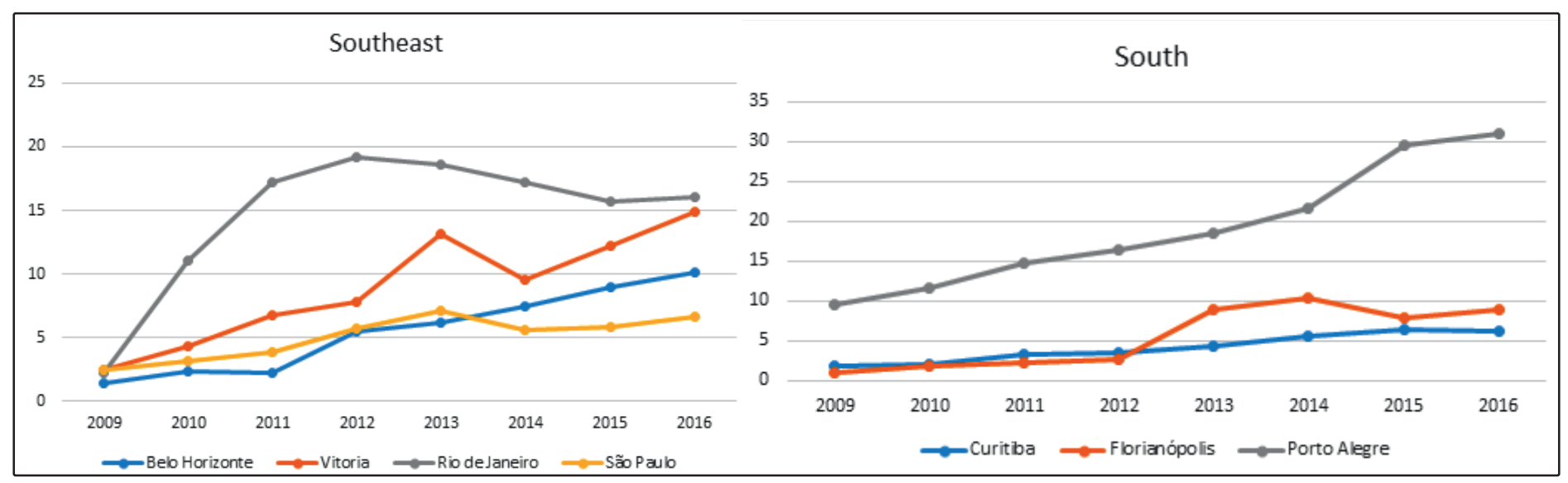

FIGURE 2: Distribution of congenital syphilis rates* in children under one year of age living in the capitals of the Southeast and South regions of Brazil from 2009 to 2016 . *Per 1000 live births.

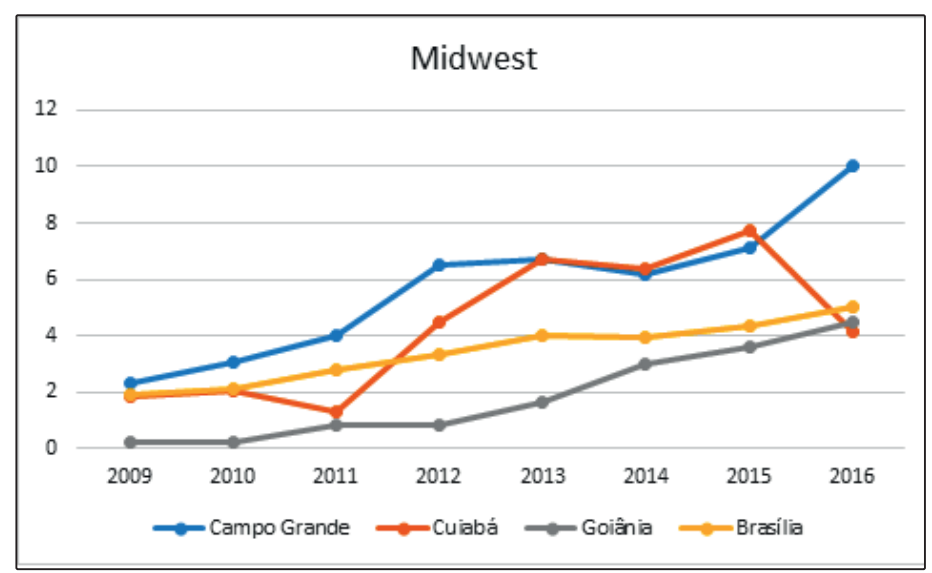

FIGURE 3: Distribution of congenital syphilis rates ${ }^{*}$ in children under one year of age living in the capitals of the Midwest region of Brazil from 2009 to 2016. *Per 1000 live births.

According to information from the Ministry of Health, the notification of cases of congenital syphilis has generally grown in Brazil, especially since 2010. In 2006 the rate was 2.0 cases/ thousand live births, and in 2015, it rose to 6.5 cases/thousand live births ${ }^{12}$, which is well beyond the maximum incidence rate indicated by the Pan American Health Organization (PAHO), which is 0.5 cases/thousand live births ${ }^{13}$.

The reason for the growth in the number of cases over the years is ambiguous. A number of studies assume that the increase in these numbers may not necessarily be associated merely with the increase in cases, but rather, be related to improvements in the records and in the notification system, training of health professionals, expansion of prenatal coverage due to the implementation of the Family Health Strategy health teams, and an increase in the effective work of the epidemiological surveillance programs ${ }^{14}$.

Implemented in 2011 by Ordinance No. 1,459 of June 24, the Ministry of Health Program - Rede Cegonha aims to structure and reorganize Brazilian maternal and child healthcare by adopting significant strategic measures such as facilitating access to Basic Health Units for rapid tests, continuous training for primary care professionals, and improvement of information systems records ${ }^{15}$.
Horta et al. ${ }^{16}$ attributed the increasing rates of congenital syphilis to inadequate or nonexistent treatment for the disease during pregnancy. It was found that $43 \%$ of pregnant women attended six or more prenatal consultations; however, only $3 \%$ underwent a VDRL in the $1^{\text {st }}$ trimester and another in the $3^{\text {rd }}$ trimester of their pregnancies, which suggests failures in the prevention and control of syphilis on the part of the health professionals ${ }^{17}$. A survey carried out between 2007 and 2013 showed that the treatment for syphilis during pregnancy was considered inadequate or incomplete in $64.8 \%$ of cases $^{18}$.

A descriptive study carried out in Rondônia from 2009 to 2014 found that $60.1 \%$ of the mothers learned about the diagnosis of congenital syphilis during prenatal care, and $28.28 \%$ only at the time of delivery or curettage ${ }^{19}$. A study carried out in Rio de Janeiro from 2011 to 2014 showed that $43 \%$ of the women were diagnosed with syphilis during prenatal care and $44 \%$ during childbirth/ curettage ${ }^{20}$. This high rate of diagnosis in the postpartum period may be caused by the failure to perform the VDLR test, which the Ministry of Health recommends to be performed in the $1^{\text {st }}$ and $3^{\text {rd }}$ trimesters of pregnancy. Therefore, congenital syphilis is still a neglected disease despite all the protocols recommended by the Ministry of Health ${ }^{21}$.

The identification of pregnant women with syphilis must be done early so that there is a quick and effective decision making regarding the treatment. To identify and elaborate actions to control gestational syphilis, the PAHO and the World Health Organization (WHO) suggest monitoring indicators aimed at reducing transmission to the fetus, thereby avoiding negative outcomes. Among the proposed indicators are the following: pregnant women attending at least one prenatal visit, conducting the tests for syphilis, and for those infected, receiving at least one dose of benzathine penicillin ${ }^{22,23}$.

In Brazil, syphilis is more prevalent in pregnant women who do not attend prenatal care ${ }^{24}$, in those with greater social vulnerability ${ }^{25}$, and in those residing in locations with difficult accessibility to syphilis testing laboratories ${ }^{26}$.

Modeling studies indicate that an important element in attaining the goal of eliminating congenital syphilis would be the treatment of all sexual partners of women diagnosed with syphilis. According to data from SINAN ${ }^{27}$, in 2015 only $13.9 \%$ of the sexual partners 
received treatment for syphilis. It is noteworthy that treatment of the partner is fundamental to avoid reinfection in the pregnant woman, and failure to perform this treatment, or the performance of an inadequate treatment, is one of the criteria adopted by the Ministry of Health to define a case of congenital syphilis ${ }^{20}$.

It can be understood based on studies ${ }^{28}$ that the expansion with quality of care in the Family Health Strategy and adherence to the Cegonha Network are elements that contributed to the improvement of notification and, consequently, the real increase in the number of cases of congenital syphilis in Brazil. However, some obstacles, such as unprotected sexual practices, are challenging in interrupting the congenital syphilis transmission chain ${ }^{29}$.

The complexity of the diagnosis of congenital syphilis in newborns (NBs) infected with T. pallidum must also be considered. The infected NB, in most cases, is asymptomatic at birth, the VDRL titers may be much lower compared to the maternal titration at this stage of life and the deficiency of the appropriate test for diagnosis in the public health network (CSF test) ${ }^{29}$. This denotes the fragility of the system, underreporting, late diagnosis, and, consequently, more severe complications to the child.

This study had limitations due to the use of secondary data in the public domain, with the possibility of underreported data, implying that the incidence rates may be higher than the ones shown. Another limitation that reduced the comparison power of the findings was the scarcity of reported data regarding the distribution of congenital syphilis at the national level over time. However, the SINAN is an official system with robust information and is widely used in scientific research studies, which bring important results to support the planning of public policies and effective changes in the epidemiological scenario of a given region and even the country.

\section{ACKNOWLEDGEMENTS}

We offer our deepest gratitude to the academic institutions that provided technical support for the development and writing of this article.

\section{AUTHORS' CONTRIBUTION}

ASR: Conception and design of the study, Acquisition of data; LCC: Analysis and interpretation of data, final approval of the version to be submitted; LSR: Critical review of the manuscript; RASG: Critical review of the manuscript; FMAMS: Critical review of the manuscript; ADJ: Analysis and interpretation of data, Final approval of the version to be submitted; LSR: Analysis and interpretation of data; Acquisition of data, Drafting the article, Final approval of the version to be submitted.

\section{CONFLICTS OF INTEREST}

The authors declare that there are no conflicts of interests.

\section{REFERENCES}

1. Suto CSS, Silva DL, Almeida EDS, Costa LEL, Evangelista TJ. Prenatal care for pregnant women diagnosed with syphilis. J Nurs Health Care. 2016;5(2):18-33.

2. Oliveira KTA, Morais LE, Leitão JMSR, Verde RMCL, Nascimento $\mathrm{MH}$, Oliveira TR, et al. Characterization of syphilis in pregnant women in the municipality of Codó - Maranhão from 2012 to 2017. Rev Eletrônica Acervo Saúde. 2019;19(19):e236-e236.

3. Souza BSO, Rodrigues RM, Gomes RML. Epidemiological analysis of reported cases of syphilis. Rev Soc Bra Clín Méd. 2018;16(2):94-8.

4. World Health Organization (WHO). Investment case for eliminating mother-to-child transmission of syphilis: promoting better maternal and child health and stronger health systems. Geneva: WHO; 2012. 30 p.

5. Ministério da Saúde (MS). Secretaria de Vigilância em Saúde. Boletim Epidemiológico - Sífilis Brasília: Departamento de Condições Crônicas e Infecções Sexualmente Transmissíveis - DCCI; Edição especial de 2019. Brasília: DF; 2019.43 p.

6. Domingues RMSM, Leal MC. Incidence of congenital syphilis and factors associated with vertical transmission of syphilis: data from the study Born in Brazil. Cad Saude Publica. 2016;32(6):8421-33.

7. Domingues RM, Szwarcwald CL, Souza Junior PR, Leal MC. Prevalence of syphilis in pregnancy and prenatal syphilis testing in Brazil: birth in Brazil study. Rev Saude Publica. 2014;48:766-74.

8. Rocha RP, Magajewski FRL. Historical Trend - Epidemiological of Congenital Syphilis in the State of Santa Catarina in the period 20072016. Arq Catarin Med. 2018;47(4):39-52.

9. Teixeira LO, Belarmino V, Goncalves CV, MendonzaSassi RA. Temporal trend and spatial distribution of congenital syphilis in the state of Rio Grande do Sul between 2001 and 2012. Cien Saude Colet. 2018;23(8):2587-97.

10. Furtado MFS, Brazil GVDS, Aragon FBA, Santos GRB, Pereira SLM, Fontoura $\mathrm{C}$, et al. Epidemiological factors of syphilis in pregnant women in the city of São Luís - MA. Rev UNINGÁ. 2018;52(1).

11. Sandes MF, Mendonça RC, Alves MMS, Santos LG, Lima MG, Farias RO, et al. Epidemiological analysis for congenital syphilis in children under one year old in the state of Sergipe/Epidemiological analysis of congenital syphilis in children of a year in the state of Sergipe. Braz J Hea Rev. 2019;2(3):1609-15.

12. Ministério da Saúde (MS). Dados epidemiológicos da sífilis em mulheres grávidas. Boletim Epidemiológico AIDS e DST. Volume 47, No 35. Brasília: MS; 2016. 29 p.

13. Pan American Health Organization (PAHO). Regional strategic plan for HIV/AIDS/STI, 2006-2015: mid-term evaluation. Progress Reports on Technical Matters. 150th Session of The Executive Committee. Washington: PAHO; 2012. 51 p.

14. Araújo CL, Shimizu HE, Sousa AIA, Hamann EM. Incidence of congenital syphilis in Brazil and its relationship with the Family Health Strategy. Rev Saude Publica. 2012;46(3):479-86.

15. Ministério da Saúde, Gabinete do Ministro. Portaria $n^{\circ} 1.459$, de 24 de junho de 2011. Institui, no âmbito do Sistema Único de Saúde - SUS - a Rede Cegonha. Diário Oficial da República Federativa do Brasil. Brasília: Ministério da Saúde; 2011.

16. Horta HHL, Martins MF, Nonato TF, Alves MI. Pré-natal do parceiro na prevenção da sífilis congênita. Rev APS. 2017;20(4):623-27.

17. Rodrigues CS, Guimarães MDC. Syphilis positivity in puerperal women: still a challenge in Brazil. Rev Panam Salud Publica. 2004;16(3):168-75.

18. Lafetá KRG, Martelli Júnior H, Silveira MF, Paranaíba LMR. Maternal and congenital syphilis, underreported and difficult to control. Rev Bras Epidemiol. 2016;19(1):63-74.

19. Moreira KFA, Oliveira DM, Alencar LN, Cavalcante DFB, Pinheiro AS, Orfão NH. Profile of reported cases of congenital syphilis. Cogitare Enferm. 2017;22(2):e48949. 
20. Reis GJD, Barcellos C, Pedroso MDM, XavierDR. Intra-urban differentials of congenital syphilis: predictive analysis by neighborhoods in the city of Rio de Janeiro, Brazil. Cad Saude Publica. 2018;34(9):e00105517.

21. Ministério da Saúde, Secretaria de Vigilância em Saúde, Departamento de Vigilância, Prevenção e Controle das Infecções Sexualmente Transmissíveis, do HIV/Aids e das Hepatites Virais. Brasília: Editora do Ministério da Saúde; 2018. 40 p.

22. World Health Organization (WHO). Global guidance on criteria and processes for validation: elimination of mother-to-child transmission of HIV and syphilis, 2nd edition. Geneva: WHO; 2017. 39 p.

23. Pan American Health Organization (PAHO). Field guide for implementation of the strategy and plan of action for elimination of mother-to-child transmission of HIV and congenital syphilis in the Americas. Washington: PAHO; 2014. 90 p.

24. Domingues RMSM, Szwarcwald CL, Souza Junior PRB, Leal MC. Prevalence of syphilis in pregnancy and prenatal testing: Study Born in Brazil. Rev Saude Publica. 2014;48(5):766-74.
25. Viellas EF, Domingues RMSM, Dias MAB, Gama SGN, Theme Filha MM, Costa JV, et al. Assistência pré-natal no Brasil. Cad Saude Publica. 2014;30(Suppl 1):S85-100.

26. Blencowe H, Cousens S, Kamb M, Berman S, Lawn JE. Lives Saved Tool supplement detection and treatment of syphilis in pregnancy to reduce syphilis related stillbirths and neonatal mortality. BMC Public Health. 2011;11(Suppl 3):S9.

27. Ministério da Saúde (MS). Secretaria de Vigilância em Saúde. Departamento de DST, Aids e Hepatites Virais. Boletim Epidemiológico Sífilis 2016. Brasilia: MS; 2016. 32 p.

28. Souza RR, Silva PI, Oliveira DL, Nascimento MA, Carvalho VM. Perfil de casos notificados de sífilis congênita no Estado de Goiás entre 2015 a 2018. Braz J Develop. 2020;6(7):48715-25.

29. Silva MJN, Barreto FR, Costa MCN, Carvalho MSI, Teixeira MG. Distribuição da sífilis congênita no estado do Tocantins, 2007-2015. Epidemiol Serv Saude. 2020;29(2):e2018477. 